\title{
O mercado mundial no pensamento de Karl Marx
}

\section{Rodrigo Straessli Pinto Franklin}

\begin{abstract}
Resumo:
$\mathrm{O}$ artigo sistematiza as principais indicações de Karl Marx sobre sua compreensão a respeito do funcionamento do mercado mundial. Inicia-se pela análise da composição desse mercado mundial à época de Marx, observando que o mesmo consistia em um amálgama de sociedades dominadas por distintos modos de produção. Após aprofundar na forma como Marx via a divisão internacional do trabalho, o artigo se volta para o fluxo de valor entre nações que se depreende das trocas internacionais e para o papel que a expansão do mercado mundial desempenha como resolução temporária das contradições imanentes à acumulação capitalista e suas crises.
\end{abstract}

Palavras-chave: Karl Marx; Mercado Mundial; Divisão Internacional do Trabalho.

\section{The world market in the Karl Marx's thought}

\begin{abstract}
:
This paper summarizes the main indications of Karl Marx about his understanding on the functioning of the world market. It begins by analyzing the composition of this world market at the time of Marx, noting that it consisted of an amalgam of societies dominated by different modes of production. After furthering in the way Marx conceived the international division of labour, the paper turns to the flow of value between nations resultant from the international exchange and for the role that the expansion of the world market plays as a temporary resolution of the capitalist accumulation's immanent contradictions and its crises.
\end{abstract}

Key-words: Karl Marx; World Market; International Division of Labour.

\section{Classificação JEL: B14, F00.}

Não devemos nos surpreender se os livre-cambistas não podem compreender como um país pode enriquecer à custa de outro, pois esses mesmos senhores não querem compreender como, no interior de um país, uma classe pode enriquecer à custa de

outra classe.

Karl Marx, 1848.

1 Professor do Departamento de Economia da Universidade Federal do Espírito Santo. 


\section{Introdução}

A epígrafe que inspira o presente artigo foi retirada do "Discurso sobre a questão do livre comércio", proferido por Karl Marx na Associação Democrática de Bruxelas em janeiro de 1848. Tal discurso é famoso pelo seu desfecho inesperado: após elencar uma série de argumentos que indicam como o livre mercado pode ser prejudicial para a classe trabalhadora, e como na realidade essa política favorece apenas aos interesses dos capitalistas, Marx termina por proferir seu voto a favor dessa prática.

Esse posicionamento controverso evidencia que, por mais que Marx não tenha desenvolvido de forma sistemática uma interpretação sobre o funcionamento e o papel do mercado mundial, ele possuía uma ideia precisa dos impactos causados pela integração econômica internacional tanto para a qualidade de vida imediata dos trabalhadores no interior de uma nação quanto para o desenvolvimento histórico da humanidade como um todo.

O fato é que esse tema sempre foi apontado pelo autor como um elemento fundamental para a compreensão das determinações econômicas nas sociedades modernas. Quando Marx traçou os seis pontos do plano inicial de "O capital”, por exemplo, o autor reservou os dois momentos finais para tratar do tema do mercado mundial, compreendendo os seguintes assuntos: relação internacional da produção; divisão internacional do trabalho; troca internacional; exportação e importação; curso do câmbio; e, por fim, o mercado mundial e as crises (MARX, 2011, p. 61).

Todavia, à medida que escrevia sua obra, esses temas foram eliminados do planejamento de Marx e relegados a uma futura continuidade de sua pesquisa, que nunca chegou a acontecer ${ }^{2}$. A despeito desse ocorrido, é possível encontrar difundidos por todos os seus escritos - desde "A ideologia alemã", até às cartas que escrevera pouco antes de sua morte, passando, é claro, por "O capital" - alguns indícios do modo como o autor pensava essas questões.

Esses são os elementos que sintetizamos aqui com o intuito de dar forma à teoria do mercado mundial de Karl Marx, auxiliando na apreensão sobre o significado de sua visão internacionalista. Contudo, devemos alertar o leitor de que não encontrará aqui uma teoria plenamente elaborada, mas apenas algumas evidências de como o autor compreendia o desenvolvimento desigual que resulta das contradições presentes nas relações econômicas do mercado mundial.

Orientando-nos pelo planejamento original de Marx, dividimos nossa exposição em três tópicos, além desta introdução e da conclusão. No primeiro, voltamo-nos para as relações internacionais de produção e a divisão internacional do trabalho, evidenciando a composição heterogênea do mercado mundial com o qual Marx se deparava, no qual era possível observar tanto relações entre nações capitalistas industrializadas quanto entre essas e os modos de produção "arcaicos".

Em seguida, voltamo-nos para o tema das trocas internacionais, evidenciando como o autor compreendia as desigualdades que derivavam do mercado mundial

2 Uma análise da evolução do planejamento de Marx, evidenciando o momento em que os temas sobre o comércio exterior e o mercado mundial foram “abandonados”, foi feita por Rosdolsky (2001, cap. 2). 
quando modos de produção com divergentes graus de acumulação estabeleciam relações de interdependência. Por fim, abordamos o papel que a expansão do mercado mundial desempenha como resolução temporária das contradições imanentes à acumulação capitalista e suas crises.

\section{Relações internacionais de produção e divisão internacional do trabalho}

"Mercado" é o âmbito no qual se dão as trocas dos produtos na forma de trocas de mercadorias. A localização e o alcance de um mercado são determinados pela localização de origem de seus participantes, os vendedores e compradores. Nesses termos, um mercado "local" é aquele no qual os participantes se restringem à proximidade geográfica, enquanto que um mercado "nacional" envolveria todos que se encontram dentro das fronteiras de um mesmo país.

De forma análoga, poderíamos dizer que o "mercado mundial", mercado dos mercados, consiste em um âmbito de troca de mercadorias do qual participam vendedores e compradores de todas as partes do globo. Qualquer mercadoria que se venda para longínquas regiões geográficas, e que concorre com outras tão longínquas produções, está, por assim dizer, sendo transacionada nesse etéreo mercado mundial.

O mercado consiste na esfera da circulação das mercadorias, em oposição à esfera da produção, da qual essas se originam. Contudo, as relações de troca de mercadorias são relações de troca de produtos do trabalho humano, de modo que os mercados são a esfera da circulação de dadas relações sociais da produção e de dada divisão social do trabalho.

Do mesmo modo, o mercado mundial enquanto esfera de circulação oculta por trás de si uma organização internacional da produção que articula todos os produtores (proprietários de mercadorias) em uma única e universal sociedade humana. Organização essa que foi elevada a um completo novo nível com o advento do modo de produção capitalista, como ressaltam Marx e Engels em "Manifesto do partido comunista":

Pela exploração do mercado mundial, a burguesia tornou cosmopolita a produção e o consumo de todos os países. Para grande pesar dos reacionários, retirou da indústria sua base nacional. As antigas indústrias nacionais foram aniquiladas e ainda continuam a ser nos dias de hoje. São suplantadas por novas indústrias cuja introdução se torna uma questão de vida ou de morte para todas as nações civilizadas: essas indústrias não empregam mais matérias-primas locais, mas matérias-primas provenientes das mais longínquas regiões, e seus produtos acabados não são mais consumidos somente in loco, mas em todas as partes do mundo, ao mesmo tempo. As antigas necessidades, antes satisfeitas pelos produtos locais, dão lugar a novas necessidades que exigem, para sua satisfação, produtos dos países e dos climas mais remotos. A auto-suficiência e o isolamento regional e nacional de outrora deram lugar a um intercâmbio generalizado, a uma interdependência geral entre as nações (MARX; ENGELS, 2001, p. 29-30). 
A interdependência geral entre indivíduos, que aparece como interdependência geral entre nações, é o resultado do desenvolvimento do modo de produção capitalista. Entretanto, não se pode confundir essa interdependência com igualdade de condições na participação desse mercado mundial.

Primeiro, é preciso observar que, como ressalta Marx, a lógica de acumulação do capital leva a um desenvolvimento desigual das diferentes economias nacionais, fundando uma espécie de divisão internacional do trabalho que divide o globo entre nações agrárias e nações de produção hegemonicamente mecanizada ${ }^{3}$. Além disso, o autor também argumenta que há desigualdades nas relações econômicas que se estabelecem entre as nações industrializadas, conforme há divergências em seus graus de desenvolvimento. Vejamos esses dois tópicos com mais detalhes.

\subsection{A divisão internacional do trabalho}

No mercado mundial analisado por Karl Marx, o monopólio da indústria mecanizada é garantido ao modo de produção capitalista, com sua capacidade e necessidade única de revolucionar permanentemente os instrumentos de produção. Já a produção agrícola pode ser realizada tanto pelo capital quanto por modos arcaicos de produção, que se utilizam das relações de trabalho servil, escravista etc.

De qualquer forma, independente da lógica que rege a produção agrícola, as funções que esse intercâmbio internacional desempenha para os países industrializados são sempre as mesmas: por um lado, as nações agrícolas consubstanciam-se em mercados para a sempre crescente produção mecanizada, ampliando a taxa de lucro e adiando as crises de superprodução; por outro, são fontes de matéria-prima para o insaciável sistema fabril e de bens de subsistência para a classe trabalhadora.

Entretanto, o efeito que a integração ao mercado mundial gera nas nações agrícolas depende da forma como se organiza a produção em seu interior. Marx analisou esses efeitos divididos em dois grupos distintos: os modos de produção arcaicos ou pré-capitalistas, e as economias coloniais.

Os modos de produção arcaicos são aqueles em que as relações sociais de produção são baseadas na servidão, escravidão etc. Seus exemplos são as sociedades feudais, o modo de produção asiático, entre outros. Antes de se integrarem ao mercado mundial, essas sociedades autônomas - i.e., que não necessitam de suas relações exteriores para garantir sua constante reprodução - são marcadas por uma divisão do trabalho interna que opõe o campo, onde se realiza a produção agrícola, à cidade, lar de uma pequena indústria doméstica e artesanal. Como a finalidade de sua produção é a geração de valores de uso para o consumo da sociedade, as trocas

3 “[...] Cria-se, assim, uma nova divisão internacional do trabalho, adequada às principais sedes da indústria mecanizada, divisão que transforma uma parte do globo terrestre em campo de produção preferencialmente agrícola voltado a suprir as necessidades de outro campo, preferencialmente industrial [...]”(MARX, 2013, p. 523). 
com o exterior restringem-se à produção que excede suas necessidades, pela qual se obtém mercadorias que poderiam ser consideradas supérfluas para sua lógica de reprodução.

Esse comércio exterior, quando não se eleva a uma forma de capital mercantil, permanece sem promover alterações significativas a esses modos de produção. Entretanto, cedo ou tarde as nações capitalistas (sejam industriais ou mercantis) estabelecem laços comerciais com esses mercados ainda inexplorados. Esse cenário é inevitável, uma vez que, como ressaltam Marx e Engels (2001, p. 29), "pressionada pela necessidade de mercados sempre mais extensos para seus produtos, a burguesia conquista a terra inteira. Tem de imiscuir-se em toda a parte, instalar-se em toda a parte, criar relações em toda a parte".

O comércio é a porta de entrada do capital em novos territórios, pois atua "[...] como solvente sobre as organizações preexistentes da produção, que, em todas as suas diferentes formas, se encontram principalmente voltadas para o valor de uso [...]” (MARX, 1986a, p. 249). A constância e escala das trocas internacionais levam essas sociedades a estabelecerem como fim de sua produção não mais a geração de valores de uso para o consumo próprio, mas a obtenção de valor de troca, de excedente exportável, com o qual o país pode adquirir as mercadorias provenientes da indústria mecanizada 5 .

Com isso, amplia-se a produção das mercadorias mais demandadas pelos países industrializados, o que pode ocorrer seguindo dois caminhos distintos. No primeiro, o comerciante se apodera diretamente da produção. $\mathrm{O}$ capital mercantil começa por encomendar as mercadorias aos produtores diretos, ditando o ritmo do trabalho. Os preços são estabelecidos pelo comerciante, que domina a produção como se fosse um capitalista industrial, permitindo-lhe se apropriar do que seria equivalente a um mais-valor gerado pelos produtores autônomos.

O próximo passo ocorre quando o capitalista mercantil passa a contratar essa força de trabalho e a põe para funcionar ainda dentro dos mesmos termos do antigo modo de produção ${ }^{6}$. A isso se dá o nome de subsunção formal do trabalho ao capital', cuja característica peculiar é a de ter na expansão absoluta do mais-valor a única forma de ampliação da taxa de exploração. Como resultado, esse processo, "[...] sem revolucionar o modo de produção, só piora a situação dos produtores diretos,

\footnotetext{
4 Veremos os detalhes dessa necessidade por mais mercados na seção 4 .

5 “[...] O desenvolvimento do comércio e do capital comercial leva por toda parte a orientação da produção para o valor de troca, aumenta seu volume, a diversifica e a cosmopolitiza [...]” (MARX, 1986a, p. 249).

6 Mas, para isso é fundamental que esse capitalista mercantil encontre a força de trabalho livre no mercado dessa nação. Veremos, a seguir, como a deterioração da pequena indústria doméstica e da produção artesanal colabora para a ampliação da oferta dessa mercadoria peculiar.

7 "[...] denominamos subsunção formal do trabalbo no capital à subordinação ao capital dum modo de trabalho tal como se tinha desenvolvido antes de ter surgido a relação capitalista [...]” (MARX, 1985a, p. 89 grifos do autor).
} 
os transforma em meros assalariados e proletários sob condições piores do que os diretamente subordinados ao capital e se apropria do seu mais-trabalho com base no antigo modo de produção [...]” (MARX, 1986a, p. 251).

O segundo caminho para a transformação do modo de produção desses países é aquele no qual o produtor se torna comerciante e capitalista. Ao invés de simplesmente atender às encomendas de um comerciante ou de clientes específicos, o produtor inicia a produção por sua própria conta. Adianta dinheiro para a aquisição dos elementos de produção, e contrata força de trabalho para atuar sob seu comando e ampliar sua escala de produção. Marx indica que esse caminho seria capaz de desenvolver a indústria manufatureira, estabelecendo a subsunção real do trabalho ao capital ${ }^{8}$ e implantando o modo de produção propriamente capitalista.

Entretanto, esse caminho revolucionador enfrentaria algumas barreiras nessas sociedades tradicionais que se integram ao mercado mundial sob a égide do capitalismo. Apesar de poder ser realizado com sucesso nos setores voltados para a exportação, muito dificilmente a indústria doméstica poderia vencer a concorrência imposta pelo capital estrangeiro com sua indústria mecanizada já consolidada: os baixos preços dos produtos importados são a ruína da produção artesanal e da indústria doméstica. Os produtores que se ocupavam com essas atividades atingem paulatinamente uma situação de pauperismo, uma vez que não conseguem concorrer com as mercadorias estrangeiras. Ao invés de se apoderarem do comércio e se converterem em capitalistas, o que normalmente se vê é a proletarização dessa parcela da população. Sua única alternativa restante é vender sua força de trabalho livre para a crescente atividade exportadora. Como Marx ressalta:

[...] o barateamento dos produtos feito à máquina e os sistemas revolucionados de transporte e de comunicação são armas para a conquista de mercados estrangeiros. Ao arruinar o produto artesanal desses mercados, a indústria mecanizada os transforma compulsoriamente em campos de produção de sua matéria-prima. Assim, por exemplo, as Índias Orientais foram obrigadas a produzir algodão, lã, cânhamo, juta, anil etc. para a Grã-Bretanha (MARX, 2013, p. 523).

Apesar de reconhecer os efeitos nocivos que essas transformações legam à população em geral, Marx tende a ver com bons olhos a dissolução dessas arcaicas relações sociais de produção e o papel "civilizador" propiciado pelo modo de produção capitalista". E o que fica claro, por exemplo, na seguinte passagem do "Manifesto do partido comunista":

8 Que permite a expansão da acumulação tanto pelo mais-valor absoluto quanto pelo relativo.

9 Mas, nas situações em que as formas anteriores de relações de produção eram condizentes com um estágio mais avançado de desenvolvimento, o autor considerava desnecessário o sofrimento que a instauração do capitalismo causava à população. Esse foi o caso, por exemplo, da Rússia, região onde sobrevivia a propriedade comunal rural. Marx deixou claro em carta enviada à revolucionária Vera Ivanovna Zasulich que, caso o comunismo fosse alcançado na Rússia antes dessa forma de propriedade ser solapada pelo capitalismo crescente, ela poderia se mostrar como uma alavanca da regeneração social daquela nação. Cf. Marx (2013, p. 849-850). 
[...] a burguesia impele todas as nações, mesmo as mais bárbaras, para a torrente da civilização. Os preços baixos de suas mercadorias são a artilharia pesada que derruba todas as muralhas da China, que obriga os bárbaros xenófobos mais renitentes a capitularem. Obriga todas as nações, sob pena de arruinarem-se, a adotarem o modo de produção burguesa; obriga-as a introduzirem em seu seio a chamada civilização, isto é, compele-as a tornarem-se burguesas [...] (MARX; ENGELS, 2001, p. 30-31).

O outro caso de integração ao mercado mundial que recebeu atenção de Karl Marx foi o das economias coloniais. Quando o autor trata das colônias, ele se refere às sociedades nas quais a terra é abundante e passível de apropriação por parte da população livre. Em suas próprias palavras, define:

[...] A essência de uma colônia livre consiste [...] em que a maior parte do solo continua a ser propriedade do povo e que cada povoador pode transformar uma parte desse solo em sua propriedade privada e em meio individual de produção, sem impedir, com isso, que os colonos posteriores realizem essa mesma operação (MARX, 2013, p. 838).

Marx utiliza o adjetivo "livre" para se referir à região colonizada por imigrantes livres ${ }^{10}$, opondo-se às colônias baseadas no trabalho escravo. As colônias escravistas surgem inicialmente como resultado da expansão do capital comercial no período mercantil. Quando essa forma de capital se faz hegemônica nas relações econômicas do mercado mundial, sua busca pela constância e escala no fornecimento de mercadorias leva-o a implantar estruturas produtivas em regiões nas quais as características geográficas favoreciam o cultivo das mercadorias consideradas exóticas para os principais mercados do mundo.

$\mathrm{Na}$ colônia escravista, por mais que a terra seja abundante e passível de apropriação por qualquer cidadão livre, a estrutura repressiva impede que o trabalhador escravizado domine-a para si, permitindo a existência de um processo de acumulação que pode ser chamado de capitalista ${ }^{11}$. Entretanto, a cooperação do trabalho em grande escala que se desenvolve nessas colônias apresenta um caráter limitado por ser fundada necessariamente no trabalho escravo, forma de relação que limita o revolucionamento do modo de produção e o desenvolvimento das relações essencialmente capitalistas ${ }^{12}$.

10 Como ele mesmo afirma: "trata-se, aqui, de verdadeiras colônias, de terras virgens colonizadas por imigrantes livres. [...] De resto, também entram nessa categoria aquelas antigas plantações, cuja situação foi completamente alterada pela abolição da escravatura” (MARX, 2013, p. 835).

11 Que propicia, inclusive, uma taxa de lucro mais elevada em virtude tanto da baixa composição orgânica quanto da elevada taxa de exploração. Afirma Marx (1986a, p. 181): “[...] no que tange aos capitais investidos em colônias etc., eles podem proporcionar taxas de lucro mais elevadas porque lá, em geral, por causa do menor desenvolvimento, a taxa de lucro é mais alta, assim como é mais alta a exploração do trabalho graças ao emprego de escravos, cules [mão de obra asiática que trabalhava em condições análogas à escravidão] etc. [...]"

12 "A aplicação esporádica da cooperação em grande escala no mundo antigo, na Idade Média e nas 
Já a colônia livre surge como resultado de uma política expansionista de potências que concorriam pela propriedade de territórios estrangeiros. Entretanto, o desenvolvimento das forças produtivas nos países industrializados, ao tornar supérflua sua própria população, deu um novo fôlego para esse processo. Em outras palavras:

A constante "transformação em supranumerários" dos trabalhadores nos países da grande indústria estimula de modo artificial a emigração e a colonização de países estrangeiros, transformando-os em celeiros de matérias-primas para a metrópole, como ocorreu com a Austrália, convertida num centro de produção de lã (MARX, 2013, p. $523)$.

A tendência das colônias livres de se voltarem para a produção de matéria-prima agrícola é resultado tanto de sua estrutura interna quanto do grau de desenvolvimento do mercado mundial. Primeiro, é preciso observar que a abundância de terras constitui um elemento de resistência à radicação do capital industrial (MARX, 2013, p. 838), tanto agrário quanto fabril, uma vez que o imigrante livre não se disporá a vender sua força de trabalho enquanto puder utilizá-la em seu próprio proveito em solo de sua propriedade.

A atividade agrícola é o destino natural do trabalho que se desenvolve na pequena propriedade rural. Embora pudéssemos imaginar que dificilmente uma sociedade moderna conseguiria se consolidar sem uma produção manufatureira, a prévia divisão do trabalho no mercado mundial permite que as colônias especializem-se apenas nos setores agrícolas e relacionados. É o que esclarece Marx na seguinte passagem:

[...] A população toda de tal região [i.e., da região colonial], como, por exemplo, Michigan, está de início ocupada quase exclusivamente com a agricultura, sobretudo com a de produtos em massa, os únicos que pode trocar por mercadorias industriais e produtos tropicais. Todo o seu produto excedente aparece, por isso, na forma de grãos. [...] Recebem já prontos, através do mercado mundial, produtos que, sob outras circunstâncias, eles próprios teriam de produzir: vestuário, ferramentas etc. Só com base nisso é que os Estados do Sul da União puderam fazer do algodão seu produto principal. A divisão do trabalho no mercado mundial permite-lhes isso (MARX, 1986b, p. 162).

Assim, essas economias coloniais tendem à produção de monocultura agrícola, com elevado "excedente" intercambiável no mercado mundial. Esse cenário só pode começar a mudar no momento em que se esgotam as terras de propriedade co-

colônias modernas repousa sobre relações imediatas de domínio e servidão, principalmente sobre a escravidão. A forma capitalista, ao contrário, pressupõe desde o início o trabalhador assalariado, livre, que vende sua força de trabalho ao capital” (MARX, 2013, p. 409). 
mum e quando surge, assim, a figura do trabalhador livre dos meios de produção ${ }^{13}$. Mas, mesmo nesses casos, o setor agroexportador normalmente se mantém como a atividade econômica mais relevante da região ${ }^{14}$.

Portanto, vemos que, para Marx, as relações econômicas internacionais tendem a reforçar a divisão internacional do trabalho. Mesmo quando o antigo modo de produção abre caminho para as relações especificamente capitalistas, ou quando estas surgem em uma região dominada pela pequena propriedade fundiária, o capitalismo pode não ser capaz de desenvolver a grande indústria mecanizada em regiões que se especializam na produção agrícola.

Todavia, Marx não imputa qualquer valor negativo à especialização agrícola. Apesar de reconhecer que a situação do trabalhador dos modos antigos de produção inicialmente se deteriora com o surgimento das relações especificamente capitalis$\operatorname{tas}^{15}$, o autor observa que a situação dos trabalhadores nas colônias livres - mesmo daqueles que vendem sua força de trabalho e que ainda não conseguiram se apropriar de uma parcela do solo para si - é normalmente melhor do que seus congêneres dos países industrializados da Europa.

Além disso, a visão de Marx sobre essa divisão internacional do trabalho não deve ser compreendida como algo fatalista, mesmo tendo o autor evidenciado uma tendência para que ela se reforce. Apesar de não ter indicado como a transição da agricultura para o sistema fabril pode ocorrer "naturalmente", o autor argumenta que as políticas protecionistas podem atuar no sentido de acelerar artificialmente esse processo. Afirma: "o sistema protecionista foi um meio artificial de fabricar fabricantes, de expropriar trabalhadores independentes, de capitalizar os meios de produção e de subsistência nacionais, de abreviar violentamente a transição do modo de produção antigo para o moderno [...]"(MARX, 2013, p. 826).

Graças ao protecionismo, uma parcela dos produtores da pequena indústria doméstica, que de outra forma iria integrar o novo proletariado, ascende à condição de burguesia nacional, dominando o mercado interno livre da concorrência internacional. É em defesa dos interesses desse grupo que atua o protecionismo. Como

$13 \mathrm{Ou}$, ainda, pode ocorrer como nos Estados Unidos, em que o avanço do capitalismo se deu pela combinação de dois fatores: “[...] por um lado, o enorme e contínuo afluxo de pessoas que a cada ano se dirigem à América deixa sedimentos estagnados no leste dos Estados Unidos, porquanto a onda emigratória da Europa lança mais pessoas no mercado de trabalho do que o pode absorver a onda emigratória para o oeste. Por outro lado, a guerra civil americana teve como consequência uma enorme dívida pública e, com ela, uma sobrecarga tributária, o surgimento da mais ordinária das aristocracias financeiras, a doação de uma parte imensa das terras públicas a sociedades de especuladores dedicadas à exploração de ferrovias, minas etc. - em suma, a mais rápida centralização do capital. A grande República deixou, assim, de ser a terra prometida dos trabalhadores emigrantes. A produção capitalista avança ali a passos de gigante, mesmo que o rebaixamento dos salários e a dependência do assalariado ainda estejam longe de alcançar os níveis normais na Europa [...]” (MARX, 2013, p. 843-844).

14 É o que Marx (2013, p. 523) observa no caso dos Estados Unidos.

15 Exceto, é claro, quando a base do antigo modo de produção é o escravo. 
ressalta Marx (1986b, p. 247):

[...] na transformação das sociedades agrárias feudais em industriais e na correspondente luta industrial entre as nações pelo mercado mundial, o que realmente importa é o desenvolvimento acelerado do capital, que não pode ser alcançado pelas assim chamadas vias naturais, mas só por meios coercitivos. Acaba fazendo grande diferença se o capital nacional se transforma paulatina e vagarosamente em capital industrial ou se essa transformação passa a ser acelerada por meio de impostos que, mediante a política aduaneira protecionista, recai principalmente sobre proprietários de terras, camponeses médios e pequenos, e artesãos, pela expropriação acelerada dos produtores diretos autônomos, pela acumulação e concentração dos capitais aceleradas à força, em suma, pela imposição acelerada das condições do modo de produção capitalista [...].

Ou seja, o protecionismo não é mais do que uma forma de expropriar parte da população com o intuito de fundar a grande indústria. Mas, com o intuito de fazer avançar o capitalismo em beneficio exclusivo da burguesia nascente, essas políticas acabam por limitar, na opinião de Marx, o caráter revolucionário do livre mercado, tal como expôs no desfecho inesperado do já citado "Discurso sobre a questão do livre comércio":

“[...] o sistema protecionista é conservador, enquanto que o sistema do livre mercado é destrutivo. Ele dissolve antigas nacionalidades e leva ao extremo o antagonismo entre a burguesia e o proletariado. Em uma palavra, o sistema de livre comércio acelera a revolução social. É somente nesse sentido revolucionário, cavalheiros, que eu voto a favor do livre mercado" (MARX, 1848, tradução própria).

\subsection{Relações econômicas entre nações industrializadas}

Para além das diferenças que marcam a divisão internacional do trabalho, Marx deixou claro em seus escritos que não considerava homogênea a relação entre as nações industrializadas no mercado mundial. Nesse sentido, o autor distingue os integrantes desse grupo de países conforme o grau do desenvolvimento que atingiu o modo de produção capitalista. Em sua análise, utiliza a economia inglesa como exemplo de capitalismo na forma mais avançada, contrastando-a com a realidade dos países da Europa continental nos quais já havia se implantado a indústria moderna.

A nação com o desenvolvimento mais elevado do modo de produção capitalista é aquela na qual o progresso tecnológico se faz patente tanto por ser o trabalho médio mais produtivo ${ }^{16}$ como por requerer uma quantidade maior de capital

16 "Uma vez que a produção capitalista encontra-se desenvolvida num país, também se elevam aí, acima do nível internacional, a intensidade e a produtividade nacional do trabalho [...]” (MARX, 2013, p. 632). 
constante para seu funcionamento, ou seja, por ter uma composição orgânica mais elevada ${ }^{17}$. Marx considera que nessa sociedade o capital terá, naturalmente, se difundido por uma quantidade maior de setores, de forma que subsiste menos dos antigos modos de produção do que em comparação com as nações de desenvolvimento inferior ${ }^{18}$.

Com relação à condição da classe operária, ela também é muito diferente conforme o grau de desenvolvimento da nação. Observa Marx (2013, p. 79): “[...] onde a produção capitalista se instalou plenamente entre nós [i.e., entre os alemães] - por exemplo, nas fábricas propriamente ditas -, as condições são muito piores que na Inglaterra, pois aqui não há o contrapeso das leis fabris [...]”. A organização e a disciplina necessárias para pôr a operar o exército industrial ativo são responsáveis também pela elevação da articulação dos operários fora das fábricas que, por sua vez, é fundamental para garantir a imposição de limites à exploração capitalista ${ }^{19}$. Por esse motivo, quanto menos desenvolvido é o modo de produção capitalista, menos organizados são os trabalhadores e, por consequência, maior é a jornada de trabalho e mais baixos os salários.

Contudo, disso não devemos concluir que o capitalista da nação menos desenvolvida absorva uma quantidade maior de mais-valor de seus operários. Ao contrário, o que afirma Marx é que, devido à menor intensidade e produtividade do trabalho, sua taxa de exploração tende a ser menor:

17 “[...] Essa lei do aumento crescente da parte constante do capital em relação à sua parte variável é corroborada a cada passo [...] pela análise comparativa dos preços das mercadorias, comparando-se diferentes épocas econômicas de uma única nação ou nações diferentes numa mesma época. Enquanto a grandeza relativa do elemento do preço que representa apenas o valor dos meios de produção consumidos, ou seja, a parte constante do capital, estará na razão direta, a grandeza relativa do outro elemento do preço, que representa a parte que paga o trabalho ou a parte variável do capital, estará na razão inversa do progresso da acumulação” (MARX, 2013, p. 699).

18 É o que deixa claro na seguinte passagem, dentre outras: “[...] atormenta-nos [aos alemães], do mesmo modo como nos demais países ocidentais do continente europeu, não só o desenvolvimento da produção capitalista, mas também a falta desse desenvolvimento. Além das misérias modernas, aflige-nos toda uma série de misérias herdadas, decorrentes da permanência vegetativa de modos de produção arcaicos e antiquados, com o seu séquito de relações sociais e políticas anacrônicas [...]” (MARX, 2013, p. 79).

19 Em "O capital”, Marx dedica grande parte do capítulo que trata sobre a jornada de trabalho para demonstrar a relação entre a luta dos trabalhadores e o estabelecimento de uma jornada considerada "normal". O autor reconhece que "[...] o capital não tem [...] a mínima consideração pela saúde e duração da vida do trabalhador, a menos que seja forçado pela sociedade a ter essa consideração [...]" (MARX, 2013, p. 342), e constata: "a consolidação de uma jornada de trabalho normal é o resultado de uma luta de 400 anos entre capitalista e trabalhador [...]” (MARX, 2013, p. 343). Marx reserva a última seção do referido capítulo para analisar o andamento dessa luta nos países de desenvolvimento capitalista inferior ao da Inglaterra. Cf. Marx (2013, cap. 8). 
Em países em diferentes estágios de desenvolvimento da produção capitalista, e portanto com diferente composição orgânica do capital, a taxa de mais-valia [...] pode estar mais alta no país em que a jornada de trabalho normal é mais curta, do que naquele em que é mais longa. Primeiro: se a jornada de trabalho inglesa de 10 horas, devido a sua maior intensidade, for igual a uma jornada de trabalho austríaca de 14 horas, 5 horas de mais-trabalho lá, com igual divisão da jornada de trabalho, podem representar um valor mais elevado no mercado mundial do que 7 horas aqui. Segundo, lá, no entanto, uma parte maior da jornada de trabalho pode constituir mais-trabalho do que aqui (MARX, 1986a, p. 166).

Podemos dizer, então, que a taxa de exploração é maior nas nações mais desenvolvidas, pois o valor da força de trabalho é relativamente menor em comparação ao produto de valor, mesmo sendo esse produto de valor (i.e., a extensão da jornada de trabalho) absolutamente maior nas nações menos desenvolvidas ${ }^{20}$. Apesar disso, essa maior taxa de exploração não chega a ser capaz de compensar a elevada composição orgânica do capital das nações mais desenvolvidas, de modo que elas apresentam, normalmente, uma menor taxa de lucro ${ }^{21}$.

As funcionalidades do comércio exterior para os países mais avançados resultam dessas diferenças entre as nações conforme o grau de desenvolvimento do modo de produção capitalista. Além da interdependência entre essas economias, que faz com que elas necessitem mutuamente da produção estrangeira para contar como fonte de meios de produção e de meios de subsistência necessários em que o capital variável se converte ${ }^{22}$, o capitalismo mais avançado se beneficia duplamente de suas relações com o exterior.

Primeiro, as diferenças entre os níveis de produtividade do trabalho atuam em favor das economias mais desenvolvidas quando se realizam as trocas interna-

20 E, ainda, mesmo sendo menor o valor absoluto da força de trabalho nestas últimas. Marx (2013, p. 632) observa: “[...] encontraremos com frequência que o salário diário, semanal etc. na primeira nação [na nação com modo de produção capitalista mais desenvolvido] é mais elevado que na segunda [naquela em que é menos desenvolvido], ao passo que o preço relativo do trabalho, isto é, o preço do trabalho em relação tanto ao mais-valor quanto ao valor do produto, é mais alto na segunda nação do que na primeira".

21 Devemos lembrar que a taxa de lucro é calculada com base em todo o capital adiantado - capital constante (c) e capital variável (v) -, enquanto o mais-valor (m) depende apenas do capital variável e da taxa de exploração (). Assim, para uma dada taxa de exploração, a relação (taxa de lucro) será tanto menor quanto maior for a composição orgânica - i.e., a relação entre o capital constante e o variável: .

22 Relação que serve como contra tendência à queda da taxa de lucro em ambas as economias: "à medida que o comércio exterior barateia em parte os elementos do capital constante, em parte os meios de subsistência necessários em que o capital variável se converte, ele atua de forma a fazer crescer a taxa de lucro, ao elevar a taxa de mais-valia e ao reduzir o valor do capital constante. Ele atua em geral nesse sentido ao permitir a ampliação da escala da produção. Assim ele acelera, por um lado, a acumulação, por outro, também o descenso do capital variável em relação ao capital constante, e com isso a queda da taxa de lucro [...]” (MARX, 1986a, p. 180) 
cionais ${ }^{23}$. Com efeito, há uma transferência de valor que não é visível ao se analisar o movimento do dinheiro pela balança de pagamentos dos países industrializados, já que os saldos possuem uma tendência a se compensarem. No entanto:

[...] Essa diferença desaparece assim que se abstrai a forma-dinheiro. O país favorecido recebe mais trabalho de volta em troca de menos trabalho, embora essa diferença, esse a-mais, assim como no intercâmbio entre trabalho e capital de modo geral, seja embolsado por certa classe [...] (MARX, 1986a, p. 181)

Segundo, por ser menor a taxa de lucro, o novo capital que resulta do processo de acumulação do país mais desenvolvido, buscará aplicação onde a perspectiva de retorno é maior, ou seja, nos mercados das outras economias industriais. Isso é, como observa Marx (2013, p. 687), o que já acontecia na Inglaterra daquele período: “[...] a maior parte do mais-produto, que cresce anualmente e é subtraído ao trabalhador inglês sem lhe dar em troca um equivalente, não é capitalizada na Inglaterra, mas no estrangeiro [...]”.

Esses dois elementos se traduzem em apenas uma coisa: na ampliação da taxa de lucro do capital da nação mais desenvolvida em detrimento daquela obtida pelo capital estrangeiro. Isso resulta do que pode ser compreendido como uma tendência à equalização da taxa de lucro internacional ${ }^{24}$, cujo significado é que, ao mesmo tempo em que se atenua a queda da taxa de lucro em um país, amplia-se seus efeitos em outro.

Por outro lado, isso que foi exposto pode ser compreendido, também, como o processo de concentração e centralização do capital atuando em escala internacional. A visão desse fenômeno permite-nos compreender a posição de Marx (2013, p. 78) ao afirmar que "[...] o país industrialmente mais desenvolvido não faz mais do que mostrar ao menos desenvolvido a imagem de seu próprio futuro". Ou seja, não se trata de acreditar que o capitalismo alemão, por exemplo, viria a se tornar equivalente ao inglês, mas que, ao integrar o mesmo e único processo mundial de acumulação de capital, o trabalhador alemão atuaria lado a lado e em igualdade de condições com o inglês, em benefício, provavelmente, do capitalista desta última nacionalidade.

Com isso, como já foi observado para as economias agrícolas, faz sentido ao

23 Os detalhes desse intercâmbio desfavorável serão explorados na próxima seção.

${ }^{24}$ Tendência que não se concretiza efetivamente. Afinal, esse processo tendencial contínuo da equalização da taxa de lucro, ao mesmo tempo em que é retardado pelo grau de mobilidade do capital e do trabalho (MARX, 1986a, p. 150), é também contrariado pela contínua busca por mais-valor adicional - que acaba por reduzir a taxa de lucro dos setores inovadores, afastando-os da taxa geral. Quando analisamos as leis tendenciais descritas por Marx, é importante ter em mente que: “[...] em toda a produção capitalista é sempre de maneira muito complicada e aproximativa, como média nunca fixável de eternas flutuações, que a lei geral se impõe como tendência dominante" (MARX, 1986a, p. 126). 
capitalista da nação menos desenvolvida lançar mão de sua influência sobre o Estado para a implantação de barreiras alfandegárias e outras políticas protecionistas. E também da mesma forma, para além do fato de ser a classe trabalhadora quem paga os custos do protecionismo, este evidencia um efeito conservador: tais políticas têm por resultado apenas retardar a formação do mercado mundial e o avanço do processo internacional de concentração e centralização do capital, adiando, portanto, a tendência histórica da acumulação capitalista.

\section{Trocas internacionais}

Como indicamos no início da seção precedente, o mercado é o âmbito no qual ocorrem as trocas de mercadorias. Assim, do mesmo modo que podemos distinguir os mercados pela localização de seus partícipes, podemos também distinguir as trocas que acontecem em seu interior conforme seu alcance geográfico, separando-as, por exemplo, em trocas locais, regionais, nacionais e internacionais.

Para Marx, essa distinção vai além de mera taxonomia, pois o autor indica haver certa oposição entre as trocas de maior e menor alcance no que tange à forma como se desenvolve a contradição entre as dimensões qualitativas e quantitativas do valor das mercadorias. Vejamos essa questão mais de perto.

O valor é uma propriedade das mercadorias que possui substância e magnitude. No que tange à sua substância, seu aspecto qualitativo, o valor evidencia o que há de igual em todas as mercadorias: o fato de serem cristalizações de trabalho humano abstrato, resultados de "[...] dispêndio de força de trabalho humana, sem consideração pela forma de seu dispêndio [...]” (MARX, 2013, p. 116).

Somente por terem essa mesma substância social, ou seja, somente por serem valores, é que as mercadorias podem ser comparadas e, em consequência, trocadas entre si. Mas, antes do intercâmbio de mercadorias emergir do valor, é o próprio valor que emerge da contínua repetição de trocas inicialmente fortuitas dos produtos do trabalho humano. Afinal, a possibilidade real de conversão do fruto de um trabalho concretamente determinado em um produto de qualquer outra forma de trabalho é o ponto de partida para a manifestação do valor, para a percepção de que todas as atividades humanas possuem uma mesma substância.

É desse modo que o limite geográfico das trocas constitui barreira para a determinação qualitativa do valor. Se o intercâmbio de mercadorias que se realiza em um mercado local é capaz de evidenciar a equivalência entre os trabalhos de diversos tipos que se encerram em suas fronteiras, ele é, por outro lado, incapaz de relacioná-los com todos os outros que se encontram fora de seu alcance. Já a troca internacional apresenta a possibilidade de conversão entre todas as mercadorias produzidas pela humanidade, comprovando o caráter universal do trabalho abstrato. Marx afirma: 
[...] Só o comércio exterior, a transformação do mercado em mercado mundial, faz o dinheiro evolver para dinheiro mundial e o trabalho abstrato para trabalho social. A riqueza abstrata, valor, dinheiro, e em conseqüência o trabalho abstrato desenvolvem-se na medida em que o trabalho concreto se torna uma totalidade - que abrange o mercado mundial - de maneiras diferentes de trabalho [...] (MARX, 1985b, p. 1302-1303 grifos do autor).

Não só o trabalho abstrato encontra sua universalidade nas trocas internacionais, mas também o dinheiro, forma direta de manifestação do valor, só se evidencia como equivalente universal no mercado mundial. "[...] Somente no mercado mundial o dinheiro funciona plenamente como a mercadoria cuja forma natural é, ao mesmo tempo, a forma imediatamente social de efetivação do trabalho humano in abstracto. Sua forma de existência torna-se adequada a seu conceito" (MARX, 2013, p. 215).

Não é mera coincidência o fato de que as trocas de mercadorias surgem historicamente na fronteira das sociedades para, depois, se estabelecerem como relação social dominante no interior das mesmas ${ }^{25}$. A troca internacional é pressuposto histórico e teórico para a troca de mercadorias dentro de uma nação. E, como consequência, é pressuposto para o próprio capital. Marx (1985b, p. 1303 grifo do autor) afirma: "[...] a produção capitalista assenta no valor ou na conversão do trabalho contido no produto, em trabalho social. Mas isso só é possível na base do comércio exterior e do mercado mundial [...]”.

Do que foi visto para a dimensão qualitativa do valor, sua substância, o oposto pode ser observado com relação à sua dimensão quantitativa, ou seja, com relação à medida de sua magnitude. A grandeza do valor de uma mercadoria consiste no tempo de trabalho socialmente necessário para a sua produção, tempo que expressa a média da capacidade produtiva e da intensidade do trabalho de uma sociedade. É em virtude da grandeza de seus valores que se estabelecem as relações de troca entre duas mercadorias ${ }^{26}$.

Quanto menor o espaço geográfico ao qual se restringem as trocas, menor a variância da grandeza do valor, ou seja, menor é a distância que separa a capacidade de um produtor qualquer da média social. À medida que se amplia o alcance do intercâmbio de mercadorias, aumenta também a magnitude desses desvios.

25 Afirma Marx (2013, p. 162): “[...] a troca de mercadorias começa onde as comunidades terminam: no ponto de seu contato com comunidades estrangeiras ou com membros de comunidades estrangeiras. A partir de então, as coisas que são mercadorias no estrangeiro também se tornam mercadorias na vida interna da comunidade $[\ldots]$ ”.

26 Isso é válido para uma sociedade mercantil não capitalista. É sempre bom frisar que, para uma sociedade capitalista, os preços das mercadorias são determinados, em última instância, por seus preços de produção. Mas, a mesma relação que se estabelece entre a determinação da grandeza do valor e o espaço geográfico das trocas se estabelece, também, entre este e a determinação dos preços de produção. 
Por outro lado, é preciso observar que a existência de uma variância maior ou menor não é empecilho para a troca de equivalentes, mas apenas gera modificações na forma como cada produtor se apropria do valor gerado na produção. Seus efeitos são distintos conforme a diferença seja com relação à produtividade ou à intensidade do trabalho. Vejamos em mais detalhe.

Quando afirmamos que o tempo de trabalho socialmente necessário para a produção de uma determinada mercadoria consiste em um dado montante de horas de trabalho, referimo-nos a horas de trabalho realizado com intensidade e produtividade médias. Quando Marx trata da intensidade do trabalho, refere-se à quantidade de trabalho que foi efetivamente dispendida no processo produtivo, ou seja, sem levar em conta as pausas por mais breves que sejam. É nesse sentido que o autor afirma que "a intensidade cada vez maior do trabalho supõe um dispêndio aumentado de trabalho no mesmo espaço de tempo [...]”(MARX, 2013, p. 591). E completa:

[...] A jornada de trabalho mais intensiva se incorpora em mais produtos do que a jornada menos intensiva de igual número de horas. [...] O valor do produto singular [...] se mantém inalterado porque o produto custa a mesma quantidade de trabalho de antes. O número de produtos aumenta [...] sem que caia seu preço (MARX, 2013, p. 591).

Portanto, um produtor individual que aumente a intensidade de seu trabalho para além da média de sua sociedade produzirá mais mercadorias que seus concorrentes em um mesmo tempo, e as trocará por produtos que representam mais tempo de trabalho do que aquele que ele mesmo dispendeu na produção. Mas, essa troca desigual de horas de trabalho representa troca de igual quantidade de trabalho.

Isso fica mais claro ao analisarmos o que ocorre quando a intensidade do trabalho aumenta no mesmo grau para todos os produtores de um mesmo setor. Supondo que mantenham constante a quantidade de horas trabalhadas, aumentar-se-ia, nesse caso, tanto a massa de valor de uso quanto a grandeza do valor gerado. A sociedade como um todo gastaria mais dinheiro para adquirir uma proporcionalmente maior quantidade de mercadorias.

Agora, se a sociedade como um todo elevasse a intensidade do trabalho na mesma proporção, fazendo subir a média social, a relação de troca entre os tempos de trabalho permaneceria constante. A sociedade teria passado a gerar uma maior quantidade de valor de uso sem que fosse possível observar uma maior geração de valor ${ }^{27}$.

Tudo isso é bem diferente quando se trata da produtividade do trabalho. Para Marx, a produtividade se refere à quantidade de valores de uso que são gerados por

27 "Se a intensidade do trabalho aumentasse em todos os ramos industriais ao mesmo tempo e na mesma medida, o novo grau de intensidade mais elevado se converteria no grau normal, fixado socialmente no costume, e deixaria, assim, de ser contado como grandeza extensiva [...]” (MARX, 2013, p. 592). 
um determinado trabalho útil de mesma grandeza extensiva e intensiva ${ }^{28}$. Esclarece:

[...] O mesmo trabalho produz, nos mesmos períodos de tempo, sempre a mesma grandeza de valor, independentemente da variação da força produtiva. Mas ele fornece, no mesmo espaço de tempo, diferentes quantidades de valores de uso: uma quantidade maior quando a produtividade aumenta e menor quando ela diminui [...] (MARX, 2013, p. 123).

Nesse sentido, um produtor individual que aumente a produtividade de seu trabalho para além da média de seu setor produzirá mais mercadorias que seus concorrentes em um mesmo tempo, e as trocará por produtos que representam mais tempo de trabalho do que aquele que ele mesmo dispendeu na produção. Mas, se uma produtividade mais elevada não implica produção de mais valor, como esse produtor consegue se apropriar de mercadorias que valem mais do que as que produziu? Isso é possível, como nos esclarece Marx (2013, p. 392), pois “[...] o valor efetivo de uma mercadoria não é seu valor individual, mas seu valor social, isto é, ele não é medido pelo tempo de trabalho que ela de fato custa ao produtor em cada caso singular, mas pelo tempo de trabalho socialmente requerido para sua produção".

Embora a mercadoria individual desse produtor singular contenha menos tempo de seu trabalho, ela é vendida conforme a produtividade média de seu setor. Ao elevar sua produtividade, esse produtor eleva em pequena medida a produtividade média de seu setor de modo que todos os demais passarão a produzir abaixo desta na mesma medida em que ele produz acima. O que ele ganha de mais valor adicional, perdem os demais. E ainda, supondo que se mantenha constante a quantidade de horas trabalhadas pela soma desses produtores, aumentar-se-ia, nesse caso, a massa de valor de uso sem elevar a grandeza do valor gerado. A sociedade como um todo gastaria o mesmo montante de dinheiro que antes para adquirir uma quantidade maior de mercadorias, fazendo essa divergência de produtividade aparecer como uma transferência de valor interna ao setor em questão.

Agora, se todos os produtores desse setor elevassem a produtividade de seus trabalhos na mesma medida, igualando-os com a média setorial, restabelecer-se-ia a equivalência entre o valor individual e social das mercadorias. Esse setor produziria,

28 É importante não confundir o aumento da produtividade do trabalho com um de seus efeitos: a elevação da composição orgânica do capital. Esses dois conceitos possuem, para Marx, forte relação entre si, uma vez que a elevação da quantidade de valores de uso produzidos por um determinado trabalho concreto tem como pressuposto e consequência uma manipulação maior de meios de produção (MARX, 2013, p. 698-699). O equívoco crucial ao qual são levados aqueles que confundem esses dois elementos, tal como Marini (1979) e Martins (2011), é o de tentar comparar a produtividade de diferentes ramos da produção por meio da comparação de suas composições orgânicas. Mas, como Marx (2013, p. 123) deixa claro, “[...] como a força produtiva diz respeito à forma concreta e útil do trabalho, é evidente que ela não pode mais afetar o trabalho, tão logo se abstraia dessa sua forma concreta e útil [...]”, ou seja, ela não é comparável entre diferentes ramos da produção. 
então, uma maior quantidade de valor de uso sem que qualquer de seus integrantes se apropriasse de quantidade maior de valor.

Concluímos com isso que, enquanto desvios na intensidade do trabalho alteram a relação de troca em termos de horas de trabalho, mas não em quantidades de trabalho, as divergências no grau de produtividade geram uma transferência de mais valor adicional, mas não comprometem o funcionamento médio da lei do valor. $\mathrm{E}$ também, que quanto maior é o espaço abarcado pelo intercâmbio de mercadorias, maior a variância tanto da intensidade quanto da produtividade do trabalho e, devido a esta última, maior a grandeza de valor que se transfere entre produtores como consequência da troca de equivalentes.

Nas trocas internacionais, esses efeitos não só se fazem presentes como atingem o seu mais alto grau. E mais, como resultado da divisão internacional do trabalho e da desigualdade no nível de desenvolvimento da acumulação capitalista nos países industrializados, as variações entre o nível de intensidade e produtividade do trabalho tendem a variar de nação para nação. Com relação à intensidade média do trabalho no mercado mundial, Marx (2013, p. 631-632) ressalta:

Em cada país vigora certa intensidade média do trabalho, abaixo da qual o trabalho para a produção de uma mercadoria consome mais do que o tempo socialmente necessário e, por isso, não conta como trabalho de qualidade normal. [...] O mesmo não ocorre no mercado mundial, cujas partes integrantes são os diversos países. A intensidade média do trabalho varia de país a país, sendo aqui maior, lá menor. Essas médias nacionais constituem, pois, uma escala, cuja unidade de medida é a unidade média do trabalho universal. Assim, comparado com o menos intensivo, o trabalho nacional mais intensivo produz, em tempo igual, mais valor, que se expressa em mais dinheiro (MARX, 2013, p. 631-632).

Portanto, as nações que apresentam intensidade média do trabalho inferior à média universal estariam fadadas a trocar sempre mais horas de trabalho nacional por menor quantidade de horas das nações nas quais se observa maior intensidade ${ }^{29}$. Este seria, particularmente, o caso das economias que, por força do comércio exterior, se especializaram na produção agrícola, afinal, a atividade industrial, devido ao ritmo e a continuidade uniforme do trabalho, pode elevar a intensidade para além do que é possível na agricultura.

Contudo, as nações industriais atrasadas, além de contarem com um trabalho menos intensivo do que o realizado nos países de maior desenvolvimento capitalista, padecem com a diferença no grau de produtividade entre eles ${ }^{30}$. Afinal:

29 É preciso lembrar que essa relação de troca desigual em termos de horas trabalhadas representaria nada mais do que um ajustamento na aplicação da lei do valor - já que continuam a trocar quantidades iguais de trabalho -, mas ajustamento que atua sempre em desfavor de certo grupo de países.

30 Como a produtividade é propriedade do trabalho concreto, não serve de parâmetro para a comparação entre a produção de diferentes setores, tais como entre o industrial e o agrícola. Assim, os 
[...] As diferentes quantidades de mercadorias do mesmo tipo, produzidas em diferentes países no mesmo tempo de trabalho, têm [...] valores internacionais desiguais, que se expressam em preços diferentes, isto é, em quantias diferentes de dinheiro de acordo com os valores internacionais [...] (MARX, 2013, p. 632).

Todavia, as mercadorias são vendidas todas a um mesmo preço no mercado internacional ${ }^{31}$, graças à ação equalizadora do capital comercial (MARX, 1986a, p. 248). Daí advém o fato de, “[...] no mercado mundial, o trabalho nacional mais produtivo também contar como mais intensivo, sempre que a nação mais produtiva não se veja forçada pela concorrência a reduzir o preço de venda de sua mercadoria a seu valor” (MARX, 2013, p. 632). Assim:

[...] o país mais adiantado vende suas mercadorias acima de seu valor [nacional/individual], embora mais barato do que os países concorrentes. [...]. Exatamente como o fabricante que usa uma nova invenção antes de sua generalização vendendo mais barato do que seus concorrentes, e mesmo assim vende acima do valor individual de sua mercadoria, ou seja, aproveita como mais-trabalho a força produtiva de trabalho especificamente mais elevada por ele empregada [...] (MARX, 1986a, p. 181).

Do mesmo modo que o fabricante mais produtivo absorve um mais-valor adicional igual ao montante que perdem seus concorrentes, os países mais desenvolvidos - ou melhor, as classes capitalistas desses países - absorvem um mais-valor adicional que se deduz dos países concorrentes de desenvolvimento inferior.

Vimos com isso que a dimensão quantitativa do valor se opõe ao seu aspecto qualitativo, no sentido de que o trabalho abstrato só assume seu caráter de expressão universal de atividade humana no momento em que são máximas as barreiras para a equiparação entre os distintos tempos de trabalho despendidos na produção. Tal contradição mostra que, ao mesmo tempo em que a lei do valor precisa do mercado mundial para se consolidar, ela só pode funcionar com uma concomitante transferência de parcela de sua grandeza resultante da troca de equivalentes; e mais, que essa contradição se inverte (mas não se resolve), à medida que se delimita mais $\mathrm{o}$ alcance do intercâmbio de mercadorias.

Devemos ainda fazer uma observação sobre as trocas internacionais que decorrem de um assunto não tratado diretamente por Marx, mas que pode ser deduzido de suas considerações. $\mathrm{O}$ autor deixa claro que o processo de equalização da taxa de lucro e da transformação dos valores em preços de produção circunscreve-se às fronteiras nacionais, fazendo reinar, em cada país, uma taxa média de lucro compatível com o grau de desenvolvimento do capital $^{32}$. Isso porque essa equalização

efeitos descritos a seguir só se aplicariam entre as nações que exploram o mesmo tipo de atividade, e seria mais significativo entre as nações industrializadas, onde a diferença de produtividade é maior.

31 Ou melhor, a um preço aproximado.

32 Por exemplo, quando inicia seu estudo sobre os preços de produção em “O capital”, Marx (1986a, 
depende de questões relacionadas com a mobilidade espacial e setorial tanto do capital quanto da força de trabalho; mobilidade essa que se encontra normalmente restringida no âmbito do mercado mundial.

Apenas as mercadorias transacionadas nos espaços internacionais teriam seus preços nivelados conforme a unidade de medida do trabalho universal, e obedeceriam as considerações apontadas acima sobre a dimensão quantitativa do valor ${ }^{33}$. Entretanto, é preciso observar que, a partir do momento em que a exportação de capitais se torna uma realidade no comércio internacional ${ }^{34}$, tem início um movimento que influenciará a magnitude da taxa média de lucro tanto nos países exportadores quanto nos receptores, gerando desvios nos preços de produção nacionais. E com esses desvios, ter-se-ia uma transferência de mais-valor entre nações semelhante à transferência que ocorre no interior de uma nação como resultado da formação da taxa geral de lucro. Isso tudo atuaria, claro, em favor das nações com mais elevada composição orgânica do capital, i.e., com desenvolvimento capitalista mais avançado.

\section{0 mercado mundial e as crises}

Como sugerimos anteriormente, Marx e Engels apresentam, no "Manifesto do partido comunista", a expansão capitalista pelo mercado mundial como um resultado inevitável desse modo de produção. Essa visão, que já estava presente desde os esboços de "A ideologia alemã", não tem nada de fatalismo ou teleologia, mas deriva da concepção, que Marx viria a desenvolver com mais detalhes em "O capital”, de que a produção capitalista necessita do comércio exterior, é inseparável dele e, sem ele, encontraria seu fim prematuro. Afirma: "a produção capitalista não pode existir de modo algum sem comércio exterior [...]” (MARX, 2014, p. 575).

As razões dessa dependência repousam nas contradições de um modo de produção que produz valores de uso com o intuito de acumular valor de troca, ou melhor, nas crises que periodicamente afligem a grande indústria, uma vez que, como afirma Marx (1986a, p. 188), "[...] as crises são sempre apenas soluções momentâneas violentas das contradições existentes, irrupções violentas que restabelecem momentaneamente o equilíbrio perturbado". Para esse autor, a expansão do mercado mundial seria impulsionada pelo capital por constituir-se em uma solução, mesmo que temporária, para as crises. Aprofundemo-nos nessa questão.

Marx não desenvolveu de forma acabada sua teoria sobre as crises no modo de produção capitalista ${ }^{35}$, mas podemos apontar dois "tipos" de crise que teriam

p. 112) afirma: “[...] o que queremos expor nesta seção é justamente a maneira como se estabelece uma taxa de lucro geral dentro de um país [...]".

$33 \mathrm{O}$ que faz com que aquele mais-valor adicional absorvido pelos países avançados concentre-se nos capitais que se envolvem com o comércio exterior. Cf. Marx (1986a, p. 181).

34 Tal como indicamos anteriormente.

35 Os leitores a par das controvérsias sobre a teoria das crises em Marx poderão julgar polêmica a 
papel especial em seu pensamento por resultarem da própria lógica de acumulação do capital $^{36}$. Em primeiro lugar, temos a crise de superprodução de mercadorias, que consiste em se produzir mais mercadorias do que a capacidade de consumo da sociedade; capacidade que, conforme nos esclarece Marx (1986a, p. 185):

[...] não é [...] determinada pela força absoluta de produção nem pela capacidade absoluta de consumo; mas pela capacidade de consumo com base nas relações antagônicas de distribuição, que reduzem o consumo da grande massa da sociedade a um mínimo só modificável dentro de limites mais ou menos estreitos.

Portanto, trata-se de uma superprodução relativa, no sentido de que não se constitui um excesso de riqueza, mas um excesso diante da possibilidade de sua distribuição para o todo da sociedade ${ }^{37}$. O limite dessa possibilidade de distribuição encontra-se, como Marx observou ao analisar a reprodução e circulação do capital social total ${ }^{38}$, na proporcionalidade com que o capital (e, portanto, seu produto) encontra-se repartido entre os diferentes ramos de produção.

Podemos sumarizar os resultados da referida investigação, no que concerne aos interesses da presente exposição, como segue: para que a reprodução do capital social total ocorra sem perturbações, ou seja, para que a renda social seja capaz de adquirir o produto anual total, é imprescindível que a massa de valor na qual se consubstancia esse produto constitua-se em valores de uso condizentes tanto com a distribuição dessa renda como com os desejos de consumo de seus possuidores ${ }^{39}$.

Entretanto, a divisão do capital entre os ramos da produção não é racionalmente determinada a partir do desejo de consumo da sociedade e de sua complexa

forma como apresentamos esse tema aqui. Mas é preciso esclarecer que não temos o objetivo de adentrar nesse debate. Nosso intuito é apenas o de demonstrar a relação desses fenômenos com a expansão do mercado mundial, tal como está incontestavelmente presente no pensamento de Marx. Uma análise detalhada da controvérsia sobre as crises dentro do próprio pensamento marxista pode ser encontrada em Faria $(1989,1997)$.

36 Em contraposição às tantas outras formas de crise resultantes de efeitos conjunturais ou causas "externas", tais como, por exemplo, as crises financeiras decorrentes da lei bancária inglesa de 1844, esta última extensivamente criticada por Marx.

37 "Não se produz demasiada riqueza. Mas periodicamente se produz demasiada riqueza em suas formas capitalistas, antitéticas" (MARX, 1986a, p. 194).

38 Cf. Marx (2014, seç. III).

39 No caso da "reprodução simples", ou seja, a reprodução do capital na qual não se amplia a capacidade produtiva da sociedade com o reinvestimento do mais-valor, essa condição é dada pela igualdade (em termos de magnitude de valor) entre o produto consumido como capital constante no setor produtor de meios de consumo e a renda dos capitalistas (mais-valor) e trabalhadores (capital variável) do setor produtor de meios de produção - para os leitores habituados às notações dos esquemas de reprodução de Marx, isso significa: IIc $=\mathrm{I}(\mathrm{v}+\mathrm{m})$. Já para a "reprodução ampliada”, na qual parcela do mais-valor se converte em novo capital, essa condição depende, sobretudo, da demanda de capital constante do setor produtor de meios de consumo ser inferior à renda dos capitalistas $\mathrm{e}$ trabalhadores do setor de meios de produção - ou seja, IIc $<\mathrm{I}(\mathrm{v}+\mathrm{m})$. 
condição de reprodução. As decisões sobre os "quês" e os "quantos" da produção são tomadas, na realidade, tendo em vista tanto a busca desenfreada pela acumulação $0^{40}$ quanto a capacidade da grande indústria em lançar quantidades cada vez maiores de mercadorias na circulação ${ }^{41}$.

É assim que a distância entre os momentos da produção e do consumo leva os capitalistas a lançarem mercadorias na circulação sem a certeza de que estas atendem a uma necessidade social, ou seja, sem saber se são valores de uso para os consumidores. E quando os meios de consumo lançados no mercado excedem o exigido para atender as condições de reprodução do capital e, portanto, as necessidades sociais, há o que se chama de superprodução ${ }^{42}$. “[...] Uma superprodução [...] que", segundo Marx (2014, p. 631), "só poderia ser compensada por uma grande quebra, em consequência da qual fosse transferido capital de [um ramo da produção para o outro] $[\ldots] "$.

Com a crise, o equilíbrio seria restabelecido e a acumulação do capital poderia ser retomada até se deparar com outro processo de superprodução. Mas, haveria alguma possibilidade de evitar com que a sociedade passasse periodicamente por essas crises? $\mathrm{Ou}$, ao menos, haveria alguma forma de adiá-las, tornando seus ciclos mais longos? Para Marx, a expansão do mercado mundial poderia cumprir esse papel.

A circulação de mercadorias poderia ocorrer em proporções distintas das determinadas pelas condições de reprodução do capital total caso ela fosse complementada na medida da necessidade pelas trocas internacionais ${ }^{43}$. Afinal, “[...] por meio do [comércio de exportação] uma nação pode converter artigos de luxo em meios de produção ou de subsistência e vice-versa [...]" (MARX, 2013, p. 656).

Esse recurso ao mercado mundial aparece como solução natural para o ramo em superprodução no momento em que se torna óbvio o excesso relativo de mercadorias. Quando as leis da oferta e da demanda pressionam para baixo seus preços e, com eles, a taxa de lucro, o abarrotamento dos mercados onde já atuam essas indústrias as faz, então, mirar para regiões ainda inexploradas pelo capital. É a percepção desse processo que leva Marx (1986a, p. 250) a afirmar que "[...] a necessidade imanente ao [modo de produção capitalista] [...] de produzir em escala cada vez maior, leva à constante expansão do mercado mundial [...]”.

Entretanto, essa expansão, apesar de adiar os efeitos dessas crises inevitáveis, não é capaz de anulá-las por completo, pois “[...] o comércio exterior [...] não faz mais do que deslocar as contradições a uma esfera mais ampla, abrindo-lhe um

40 Como ressalta Marx (MARX, 1986a, p. 194-195), “[...] a taxa de lucro é a força impulsionadora da produção capitalista, e só se produz o que e à medida que pode ser produzido com lucro [...]"

41 "A enorme capacidade, própria do sistema fabril, de expandir-se aos saltos e sua dependência do mercado mundial geram necessariamente uma produção em ritmo febril e a consequente saturação dos mercados, cuja contração acarreta um período de estagnação [...]” (MARX, 2013, p. 524).

42 Pois com uma produção excessiva de meios de consumo teríamos: IIc $>\mathrm{I}(\mathrm{v}+\mathrm{m})$.

43 Essa possibilidade é sugerida por Marx em alguns momentos no decorrer da análise sobre a reprodução simples. Cf. Marx (2014, p. 511-512, 570-573). 
maior campo de ação” (MARX, 2014, p. 573). Se a reprodução do capital social total de uma nação requer um frágil equilíbrio entre as proporções nas quais o capital se reparte entre os ramos da produção, condições similares devem ser observadas ao se considerar a produção capitalista em todas as nações como um conjunto.

Há ainda um segundo "tipo" de crise, a crise de superprodução de capital. Essa não tem como causa, ao contrário do caso anterior, uma produção desproporcional de meios de produção. Afinal, sempre que estes são produzidos em excesso, podem ser utilizados para converter mais-valor em novo capital ${ }^{44}$. E caso aconteça dos preços serem pressionados para baixo devido ao excesso de oferta de meios de produção, isso torna o novo investimento ainda mais lucrativo, o que eleva também sua demanda.

O limite para um excesso (relativo) de meios de produção aparece quando o novo capital não encontra as condições necessárias para obter uma valorização condizente com a que se observa para o capital já aplicado, em outras palavras, se a taxa de lucro que puder obter for inferior à média social. Nesse caso, sugere Marx (1986a, p. 192):

\begin{abstract}
Seria [...] superprodução [de capital], porque o capital seria incapaz de explorar o trabalho num grau de exploração que é condicionado pelo desenvolvimento sadio, normal do processo de produção capitalista, num grau de exploração que ao menos aumenta a massa de lucro com a massa crescente de capital empregado; que, portanto, exclui que a taxa de lucro caia na mesma proporção em que o capital cresce, ou até que a taxa de lucro caia mais rapidamente do que o capital cresce.
\end{abstract}

Portanto, a verdadeira origem da superprodução de capital encontra-se na tendência progressiva da taxa de lucro a cair. Essa tendência, que foi descrita por Marx no livro terceiro de "O capital" ${ }^{45}$, resulta do fato de que, ao buscar elevar a produtividade do trabalho com o intuito de obter mais-valor adicional, a classe capitalista acaba por ampliar a massa de meios de produção manipulada por cada trabalhador e, portanto, a magnitude do capital constante com relação ao capital variável. E, como já vimos ${ }^{46}$, a uma maior composição orgânica do capital, corresponde uma taxa de lucro mais baixa.

Ao se deparar com uma lucratividade menor, a classe capitalista se abstém de converter o mais-valor em capital. Por isso, “[...] o desenvolvimento da força produtiva de trabalho gera, na queda da taxa de lucro, uma lei que em certo ponto se opõe com a maior hostilidade a seu próprio desenvolvimento, tendo de ser portanto constantemente superada por meio de crises” (MARX, 1986a, p. 194).

44 Essa conclusão é alcançada por Marx na análise dos esquemas da reprodução ampliada do capital. Produção excessiva de meios de produção implicam IIc $<\mathrm{I}(\mathrm{v}+\mathrm{m})$, que é condição necessária para a reprodução em escala ampliada. Cf. Marx (2014, p. 630-631).

45 Cf. Marx (1986a, seç. III).

46 Cf. nota 21. 
As crises são a forma mais violenta de se resolver a superprodução de capital. Mas, Marx ressalta uma série de outros elementos que podem atuar no sentido de retardar a queda da taxa de lucro, de forma a adiar o efeito da crise, porém sem nunca a eliminar. Dentre esses elementos, destacamos o papel que o autor reserva ao comércio exterior.

Primeiramente, o intercâmbio internacional de mercadorias, ao permitir a importação de meios de consumo necessários para a reprodução da classe trabalhadora a um preço inferior ao encontrado no mercado nacional, contribui para o barateamento da força de trabalho, com o efeito imediato de aumentar a taxa de exploração e, em consequência, a taxa de lucro. Além disso, colabora também para a redução do capital constante, pois, como lembra Marx (1986a, p. 82), "[...] ele afeta os preços das matérias-primas e auxiliares utilizadas na indústria ou na agricultura [...]". Com isso, reduz o montante de capital que se deve adiantar para se obter uma dada massa de lucro, elevando, portanto, sua taxa.

Ainda, o capital investido no comércio exterior obtém taxa de lucro mais elevada (que tem por efeito elevar a taxa média de lucro após sua equalização) por concorrer com capitais menos produtivos de outros países e se beneficiar, com isso, do processo de transferência de valor descrito na seção anterior. Por fim, Marx (1986a, p. 181) também nos rememora dos capitais que se investem no exterior, onde as condições de acumulação são mais favoráveis. Ao obterem lucros mais elevados nessas regiões, remetem-nos ao país de origem onde, ao participar da equalização da taxa de lucro, auxiliam a elevá-la.

Contudo, apesar de todos os seus efeitos favoráveis no sentido de afastar as crises de superprodução de capital, o próprio comércio exterior acaba por impulsioná-las. Ressalta Marx (1986a, p. 181):
O mesmo comércio exterior porém desenvolve no interior o modo de produção capita- lista, e com isso a diminuição do capital variável em relação ao constante, e produz, por outro lado, superprodução em relação ao exterior, tendo por conseguinte, no decurso posterior, também o efeito contrário [ou seja, o de gerar a queda da taxa de lucro].

Em suma, vemos que por se constituir em alívio momentâneo para as contradições da lógica de acumulação do capital - tanto nas que geram as crises de superprodução de mercadorias quanto de capital -, a expansão do comércio exterior aparece como resultado necessário do modo de produção capitalista ${ }^{47}$. Por outro lado, como o mercado mundial não faz mais do que elevar essas contradições a uma escala mais ampla, ele não elimina as barreiras que o desenvolvimento do capital impõe a ele mesmo, deixando claro que esse modo de produção possui caráter simplesmente histórico e transitório.

47 Nas palavras de Marx (1986a, p. 180): “[...] a ampliação do comércio exterior, embora tenha sido na infância do modo de produção capitalista sua base, tornou-se, em seu progresso, pela necessidade intrínseca desse modo de produção, por sua necessidade de mercado sempre mais amplo, seu próprio produto $[\ldots] ”$. 
É a junção desses dois argumentos, do fato da expansão do comércio exterior ser resultado necessário da acumulação capitalista e da concepção sobre os limites dessa acumulação, que leva Marx a concluir que é a tarefa histórica desse modo de produção preparar as condições, por meio da consolidação do mercado mundial e do desenvolvimento das forças produtivas, para o surgimento de uma nova forma de relação social de produção. Pois:

[...] Se [...] o modo de produção capitalista é um meio histórico para desenvolver a força produtiva material e para criar o mercado mundial que lhe corresponde, ele é simultaneamente a contradição constante entre essa sua tarefa histórica e as relações sociais de produção que lhe correspondem (MARX, 1986a, p. 189).

Ao atingir seus limites históricos, o modo de produção capitalista criaria as condições para que o comunismo, forma social na qual a produção material se encontraria subjugada à consciência universal da humanidade, pudesse sucedê-lo como resultado de uma revolução de alcance mundial ${ }^{48}$.

No que tange à expansão do mercado mundial, seu papel na formação dessas condições seria duplo. Primeiro, ela seria necessária para vincular a história de todos os indivíduos em uma única "história mundial"»", tornando o desenvolvimento das forças produtivas um fenômeno ao mesmo tempo universal e irreversível ${ }^{50}$. Em segundo lugar, essa expansão criaria o sujeito histórico responsável por pôr em marcha o processo revolucionário: o proletariado. Nesse sentido, Marx e Engels (2007, p. 39 grifos dos autores) afirmam:

[...] A massa dos simples trabalhadores [...] pressupõe o mercado mundial [...]. O proletariado [...] só pode, portanto, existir histórico-mundialmente, assim como o comunismo; sua ação só pode se dar como existência "histórico-mundial”; existência histórico-mundial dos indivíduos, ou seja, existência dos indivíduos diretamente vinculada à história mundial.

48 Em uma anotação marginal ao manuscrito de "A ideologia alemã”, Marx afirma que "[...] o comunismo, empiricamente, é apenas possível como ação 'repentina' e simultânea dos povos dominantes $[\ldots]$ ", de modo que "[...] sem isso, [...] o comunismo poderia existir apenas como fenômeno local, [...] e [...] toda ampliação do intercâmbio superaria o comunismo local [...]” (MARX; ENGELS, 2007, p. 39). Essa passagem reforça a ideia de que, para esse autor, o comunismo só seria possível como um fenômeno mundial.

49 “[...] Quanto mais o isolamento primitivo das nacionalidades singulares é destruído pelo modo de produção desenvolvido, pelo intercâmbio e pela divisão do trabalho surgida de forma natural entre as diferentes nações, tanto mais a história torna-se história mundial [...]” (MARX; ENGELS, 2007, p. 40).

50 " [...] Somente quando o intercâmbio torna-se intercâmbio mundial e tem por base a grande indústria, quando todas as nações são levadas à luta da concorrência, é que está assegurada a permanência das forças produtivas já alcançadas” (MARX; ENGELS, 2007, p. 55). 
Tal visão não implica a crença de que em algum momento futuro a possibilidade do comunismo seria real. Ao contrário, ela se baseia no entendimento de que, já naquele momento, o capitalismo havia cumprido esse seu papel histórico e que, portanto, as condições de sua superação já estavam dadas, tal como podemos depreender da seguinte passagem de "A ideologia alemã":

A grande indústria [...] criou pela primeira vez a história mundial, ao tornar toda nação civilizada e cada indivíduo dentro dela dependentes do mundo inteiro para a satisfação de suas necessidades, e suprimiu o anterior caráter exclusivista e natural das nações singulares [...] E finalmente, enquanto a burguesia de cada nação conserva ainda interesses nacionais à parte, a grande indústria criou uma classe que tem em todas as nações o mesmo interesse e na qual toda nacionalidade já está destruída; uma classe que, de fato, está livre de todo o mundo antigo e, ao mesmo tempo, com ele se defronta (MARX; ENGELS, 2007, p. 60-61).

Claro que, enquanto não fosse substituído por outra forma de organização social, o modo de produção capitalista trataria de ampliar cada vez mais o mercado mundial e de se implantar por todas as partes e todos os setores. Mas o fato é que aquela conexão universal entre os indivíduos, assim como a classe internacional dos proletários, já estavam formadas. Desse modo, bastaria que os trabalhadores se sublevassem com sucesso em alguma nação na qual predominava o modo de produção capitalista para que se iniciasse uma reação em cadeia de revoluções comunistas "repentinas e simultâneas" em todos os países do mundo ${ }^{51}$

\section{Conclusão}

O presente artigo teve o propósito de sintetizar de modo coerente as principais indicações de Karl Marx sobre sua compreensão a respeito do funcionamento do mercado mundial. Iniciamos analisando a composição desse mercado mundial à época de Marx, e vimos que o mesmo consistia em um amálgama de sociedades dominadas por distintos modos de produção.

Vimos que, embora o contato do modo de produção capitalista com os modos de produção arcaicos leve estes a se modernizarem, ele também reforça a formação de uma divisão internacional do trabalho, na qual um conjunto de nações se especializa na produção agrícola, enquanto outras se voltam para a produção industrial.

E ainda, vimos que Marx indica a existência de uma relação econômica desigual entre nações industriais com distintos graus de desenvolvimento do modo de produção capitalista, que favorece duplamente aquela com maior composição

51 Nesse sentido, Engels (1975, p. 345, tradução própria) haveria sugerido: “[...] se agora, na Inglaterra ou na França, os trabalhadores libertarem a si mesmos, isso deve levar a revoluções em todos os outros países, coisa que, cedo ou tarde, trará também a libertação dos trabalhadores desses países”. 
orgânica do capital: primeiro, pelo fluxo de valor que reflui para os países de desenvolvimento mais elevado a partir das trocas internacionais - como consequência da divergência entre o grau de intensidade e produtividade do trabalho entre essas nações -; segundo por ser campo de aplicação para o capital excedente - que transfere o mais-valor obtido para o país de origem. $O$ resultado dessa relação apresenta-se como uma elevação da taxa de lucro dos países com desenvolvimento mais elevado e como um processo de concentração e centralização do capital em nível internacional.

Por fim, vimos que, para Marx, a expansão do mercado mundial é um imperativo do próprio modo de produção capitalista que, impulsionado por suas crises, é levado a buscar uma interação cada vez mais intensa com mercados nas mais longínquas regiões. Contudo, como a expansão do capitalismo pelo mercado mundial não soluciona suas contradições, mas apenas amplia sua área de atuação, o autor conclui que esse processo apenas permite ao capital concluir sua tarefa histórica: a de gerar os elementos necessários para a transformação do atual modo de produção e para a submissão das forças produtivas à consciência universal da humanidade.

Diante de tudo que foi exposto, podemos observar não só que há uma teoria consistente sobre o funcionamento e o papel do mercado mundial subjacente ao pensamento de Karl Marx, mas também que essa teoria apresenta muitos elementos compatíveis com alguns desenvolvimentos apresentados por outros marxistas que abordaram essa temática - como os autores da teoria do imperialismo e da teoria da dependência. Todavia, analisar em que medida o pensamento de Marx se aproxima dos (ou se opõe aos) autores que o seguiram seria tarefa para outra pesquisa.

\section{Referências Bibliográficas}

ENGELS, Friedrich. Principles of Communism. In: MARX, KARL; ENGELS, FRIEDRICH. Karl Marx, Frederick Engels: Collected Works. New York: International Publishers, 1975. v. 6. p. 341-357.

FARIA, Luiz Augusto Estrella. Centro, periferia e dependência: a crise do fordismo lá e cá. Ensaios FEE, Porto Alegre, v. 18, n. 2, p. 237-263, 1997.

FARIA, Luiz Augusto Estrella. O retorno da crise... e da controvérsia. In: FARIA, LUIZ AUGUSTO ESTRELLA; CONCEIÇÃO, OCTAVIO AUGUSTO CAMARGO; BELLO, TERESINHA DA SILVA. Desvendando a espuma: reflexões sobre crise, regulação e capitalismo brasileiro. Porto Alegre: FEE, 1989. p. 121-143.

MARINI, Ruy Mauro. Plusvalía extraordinaria y acumulación de capital. Cuadernos Políticos, México, n. 20, p. 18-39, abr. 1979.

MARTINS, Carlos Eduardo. Globalização, dependência e neoliberalismo na América Latina. São Paulo: Boitempo, 2011. 
MARX, Karl. Capítulo VI inédito de O capital: resultados do processo de produção imediata. São Paulo: Editora Moraes, 1985a.

MARX, Karl. Discours sur la question du libre-échange. Bruxelles: Association Démocratique de Bruxelles, 1848.

MARX, Karl. Grundrisse: manuscritos econômicos de 1857-1858; esboços da crítica da economia política. Tradução Mario Duayer; Nélio Schneider. São Paulo: Boitempo, 2011.

MARX, Karl. O capital: crítica da economia política; livro primeiro - o processo de produção do capital. Tradução Rubens Enderle. São Paulo: Boitempo Editorial, 2013.

MARX, Karl. O capital: crítica da economia política; livro segundo - o processo de circulação do capital. Tradução Rubens Enderle. São Paulo: Boitempo Editorial, 2014.

MARX, Karl. O capital: crítica da economia política; Livro terceiro - o processo global da produção capitalista. 2. ed. São Paulo: Nova Cultural, 1986a. v. 1.

MARX, Karl. O capital: crítica da economia política; Livro terceiro - o processo global da produção capitalista. 2. ed. São Paulo: Nova Cultural, 1986b. v. 2.

MARX, Karl. Teorias da mais-valia: história crítica do pensamento econômico: livro 4 de O capital. São Paulo: Difel, 1985b. v. 3.

MARX, Karl; ENGELS, Friedrich. A ideologia alemã: crítica da mais recente filosofia alemã em seus representantes Feuerbach, B. Bauer e Stirner, e do socialismo alemão em seus diferentes profetas. Tradução Rubens Enderle; Nélio Schneider; Luciano Cavini Martorano. São Paulo: Boitempo, 2007.

MARX, Karl; ENGELS, Friedrich. Manifesto do Partido Comunista. Porto Alegre: L\&PM, 2001.

ROSDOLSKY, Roman. Gênese e estrutura de O capital de Karl Marx. Tradução César. Benjamin. Rio de Janeiro: Contraponto, 2001. 